\title{
Research on Financial Analysis of Modern Enterprise Based on Economic Added Value and DuPont Financial Analysis
}

\author{
Wang Xianglan ${ }^{1 *}$ Fu Xingfeng ${ }^{2}$ \\ ${ }^{1}$ School of Business Administration, South China University of Technology, Guangzhou 501641 China \\ ${ }^{2}$ Guangzhou Automobile Group CO.,LTD Automotive Engineering Institute, Guangzhou 501640 China \\ *Corresponding author. Email: fxf1000@163.com
}

\begin{abstract}
Financial statements are the commercial language for enterprises to communicate with the outside world. They play an increasingly important role in economic life. The items in financial statements are highly general and concentrated. Only through appropriate financial analysis can they become useful information for accounting information users to make decisions. Dupont financial analysis system can comprehensively evaluate the financial status and operating results of an enterprise. However, with the increasing complexity of the enterprise's operating activities, especially for diversified group enterprises, the traditional Dupont financial analysis system has certain limitations. Therefore, on the basis of constructing a weighted modified economic added value theoretical model, this paper analyses the enterprise's economic organization value and wealth creation ability, and uses the method of improving Dupont financial analysis system to analyse the financial status and operating results of an enterprise, and puts forward improvement suggestions for its existing problems.
\end{abstract}

Keywords: financial analysis, solvency, operating capacity, profitability, DuPont analysis

\section{INTRODUCTION}

Financial analysis is to achieve normal operation, effective decision-making and Important Links in Effective Management [1]. In the past, many companies had onesided maximization of profits. It's makes business decisions full of short-sighted behaviour [2]. Economic value added(EVA) is a measure of the value and wealth creation of economic organizations standard [3]. EVA is equal to net operating profit after tax minus debt and equity costs, and is equal to remaining income after deduction. EVA reflects the real situation of business operations and the degree of shareholder value creation [4].

Compared with accounting profit, economic profit is net operating profit after tax minus debt capital cost and rights [5]. Because EVA overcomes traditional enterprises some of the shortcomings in the industry's value evaluation methods provide investors with a new perspective on the company's intrinsic value and shareholders 'measurement of managers' performance, and can be effectively applied to all aspects of the company's internal management [6]. Therefore, this method is widely used to evaluate the intrinsic value of enterprises. Since the actual situation of each enterprise is different, when evaluating the internal value of the enterprise, different analysis models need to be established for analysis in order to obtain accurate results.

\section{Establishment of EVA theoretical model}

The EVA main data comes from the company's financial statements [7]. Based on the adjustment of the original accounting items, determine the capital investment and net operating profit after tax, then estimate the cost of equity capital, determine its weighted average cost, and finally calculate EVA according to the definition [8]. EVA is the adjusted net operating profit after tax minus the opportunity cost of the economic value of the company's existing assets. Its calculation formula is:

$$
\mathrm{EVA}=\mathrm{N}-\mathrm{W} \times \mathrm{T}
$$

$\mathrm{N}$ is adjusted net operating profit after tax, $\mathrm{W}$ is weighted average cost of capital, $\mathrm{T}$ is fully invested capital which includes debt and equity capital.

The EVA statement adjusts the financial accounting items prepared by the enterprise according to accounting standards [9]. Because the calculation of the root situation reflects some distortion, adjustments in the EVA schedule require certain accounting statement items, such as: writeoff of bad debt in inventory, questions, depreciation, revenue recognition, cost and evaluation, seasonal $\mathrm{R} \& \mathrm{D}$, market construction expenditure, restructuring costs, mandatory investments through inflation and currency transactions, taxation, special issues in terms of safety and environmental protection, etc [10]. Based on the adjustment of some necessary items in the accounting statement, the calculation of the adjustment of the necessary items of taxation of the enterprise is based on the operating profit 
and reflects the inherent value of the enterprise. The EVA evaluation model reveals three basic principles of value appreciation: return rate, risk, and a continuity to reflect and measure returns, and provides a reliable measure of whether the company is relying on the scale plus its intrinsic value.

\section{CONSTRUCTION OF IMPROVED DuPont FINANCIAL ANALYSIS SYSTEM}

Return on equity (ROE) is the core content of DuPont's financial analysis system and is the most comprehensive "Financial analysis ratio". It represents the profitability of the owner's invested capital, reflects the efficiency of the company's financing, investment in asset operations and other activities, and the improvement of the return on equity is the guarantee for the maximization of the owners' equity wealth They are very concerned about this financial analysis ratio. Net sales margin is the ratio of the company's net profit to sales income, which reflects how much net profit each yuan of sales income brings, indicating that the level of sales revenue of a company in a certain period of time is the profit level of the entire business process of the company. Corporate net profit is the balance of sales revenue after deducting total costs.

Generally speaking, the main factors affecting the net profit margin of sales are sales revenue and total cost. It can be seen that in the financial analysis of the enterprise, the net profit margin of sales can be further decomposed into the gross profit margin of sales, the cost of sales rate, the expense rate during sales and the sales tax rate. Gross sales margin is the ratio of gross sales profit to sales revenue. Among them, the so-called gross profit of sales refers to the difference between sales revenue and cost of sales.

This ratio reflects how much each enterprise's sales revenue can be used for expenses and profitability after deducting the cost of sales, and reflects the direct profitability of the company's comprehensive or individual products. It is the initial basis of the net profit margin for sales, and a company cannot make a profit without a sufficiently large gross profit margin. If the sales gross margin is very low, it means that the company does not have enough gross profit, and the profit level after the compensation for the period is not high, and it may not be able to make up for the period, causing the enterprise to lose money. Through the analysis of this indicator, the profitability of the enterprise can be predicted. The cost of sales ratio, corresponding to the gross profit margin of sales, is used to reflect the cost and expenditure required for each yuan of sales revenue. This unusually high financial ratio indicates that the company's sales methods are incorrect or in an unfavorable market position. It is the cost of sales as a percentage of sales revenue, indicating how much cost of sales each dollar of sales revenue occupies.

Through the analysis of sales discount ratio, you can understand the sales policies of competitors, adjust your sales strategy, increase sales revenue, and increase the net profit sales discount ratio is too high, indicating that there is a problem in the production or sales department. Asset 
efficiency of the company's current assets is reflected by the turnover rate of current assets. The turnover rate of current assets is the percentage of a company's sales revenue to total current assets. The accuracy of this ratio calculation directly affects whether it can accurately reflect the efficiency of the enterprise's current assets. Similarly, it can be reflected by the turnover days of current assets. turnover is the percentage of a company's sales revenue to total assets. It is an index that reflects the efficiency of asset use on the basis of accrual basis. It also has another expression, that is, the number of days of asset turnover.

Among the various assets of an enterprise, the utilization efficiency of current assets and fixed assets is the main factor affecting the speed of asset turnover. The utilization

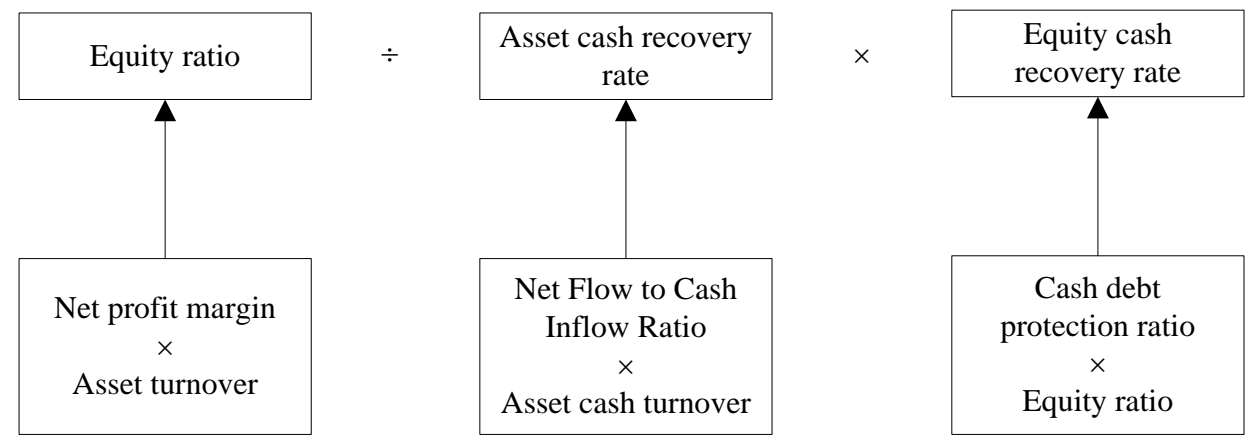

Fig. 1. The secondary analysis indicator chart of the improved DuPont financial analysis system

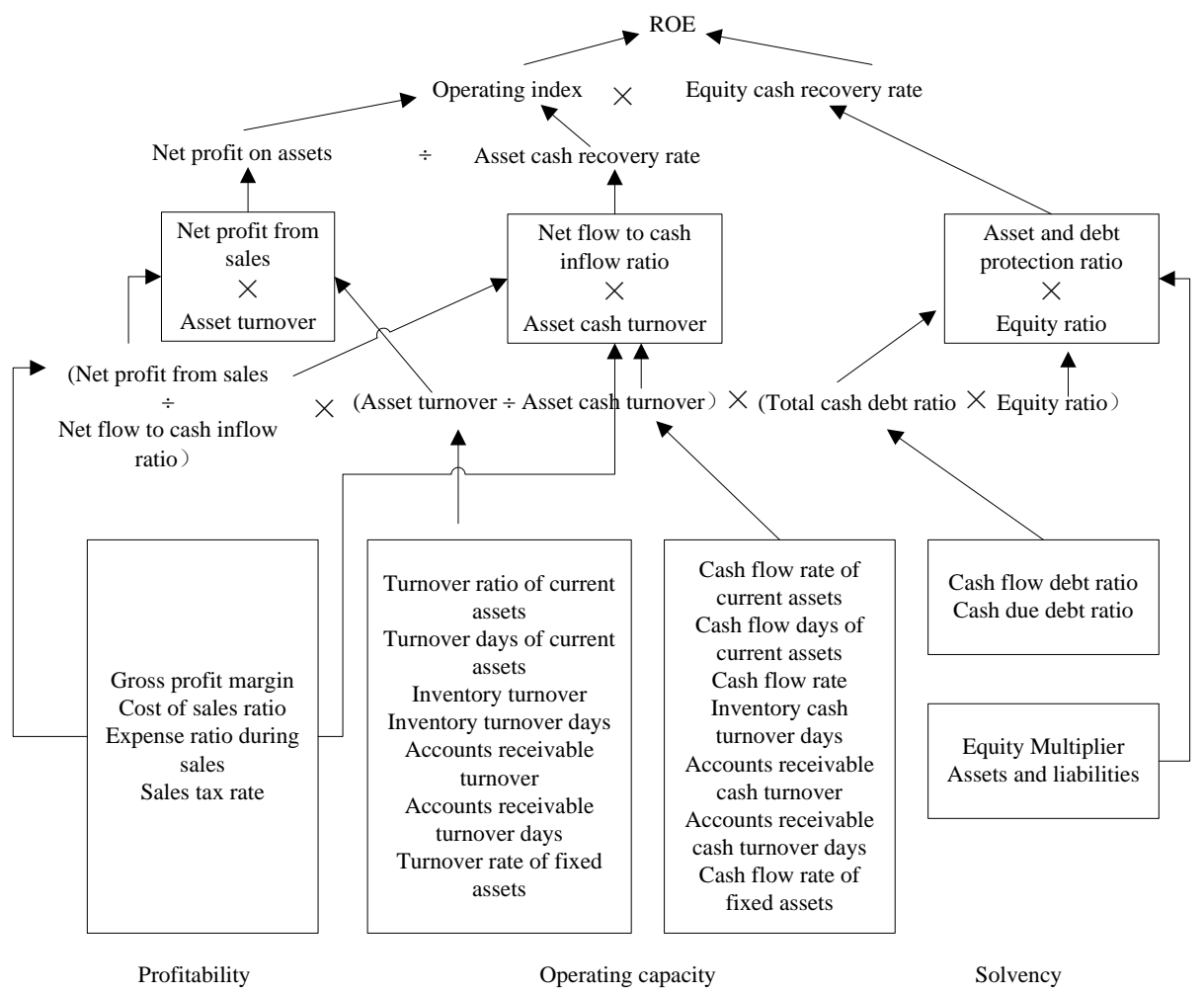

Fig. 2. Basic-level analysis indicator chart of the improved DuPont financial analysis system

Inventory turnover rate is an important index to measure and evaluate the level of inventory management of an enterprise, and its quality is related to the short-term solvency of the enterprise. In general, the larger the inventory turnover rate, the fewer the days of inventory turnover, indicating that the more liquid the inventory is, the faster it can be converted into cash or receivables. It can be seen that the improvement of inventory turnover rate will help to enhance the short-term debt repayment ability of enterprises.

The higher the accounts receivable turnover rate, or the fewer days of accounts receivable turnover, indicating that the faster the turnover rate of accounts receivable, the shorter the average collection period of the enterprise, the more efficient the use of funds, and the debt repayment of the enterprise the stronger the ability. The cash flow ratio of assets refers to the percentage of cash inflows from 
operating activities of the enterprise to the total assets. It is an indicator that reflects the efficiency of asset utilization on the basis of the realization of the payment and payment system. It not only conceptually more accurately reflects the circulation speed of all assets from the input to the output cycle during the operation of the enterprise, and reflects the management quality and overall assets of the enterprise. usage efficiency. At the same time, it also excludes the possibility that the enterprise uses the receivable items to manipulate the index value and artificially affect the evaluation results. It can also be expressed in terms of turnover days, that is, the total assets multiplied by the number of days in the calculation period and then divided by the cash inflows from operating activities.

The ability of a company's current assets to obtain cash inflows is generally measured by the cash flow rate of current assets. The cash flow rate of current assets refers to the percentage of cash inflows from operating activities of the enterprise to the total assets. The accuracy of the calculation of this ratio directly affects whether the ability of a company's current assets to obtain cash inflows can be correctly evaluated. Similarly, it can also be reflected in the cash turnover days of current assets. The larger this indicator is, the more the net cash flow from operating activities that the company can use to repay current liabilities, the higher the degree of protection for current liabilities.

Through the decomposition of the above indicators, a basiclevel analysis indicator system was constructed, and the reason for the core indicator of return on equity to change has been further specified.

\section{APPLICATION OF THE IMPROVED DuPont FINANCIAL ANALYSIS SYSTEM IN COMPANY A}

Based on the financial data published by a company, this article introduces a DuPont financial analysis system that uses cash flow indicators to analyse the profitability and prospects of a company in a comprehensive, accurate, and true way. In this case, the relevant financial data is selected from the annual financial report of Company A, and use the improved DuPont financial analysis system before and after to analyse the company's financial situation. It's shown in table 1 .

Table 1. Company A Profitability indicator

\begin{tabular}{|c|c|c|c|c|c|}
\hline Profitability indicator & 2016 & 2017 & 2018 & $\begin{array}{c}\text { Percent } \\
\text { change }\end{array}$ & $\begin{array}{c}\text { Rate of } \\
\text { change }(\%)\end{array}$ \\
\hline Profitability of total assets & 21.22 & 27.76 & 25.49 & -2.27 & -8.91 \\
\hline OPE & 73.76 & 71.67 & 64.48 & -7.19 & -10.03 \\
\hline Net profit margin of total assets & 14.7 & 19.07 & 15.88 & -3.19 & -16.73 \\
\hline Cost expense margin & 219.57 & 176.53 & 142.08 & -34.06 & -19.52 \\
\hline Operating margin & 58.55 & 56.55 & 50.13 & -6.42 & -11.35 \\
\hline Main business cost ratio & 7.01 & 7.27 & 8.37 & 1.1 & 15.13 \\
\hline Sales margin & 41.53 & 40.58 & 36.04 & -4.54 & -11.19 \\
\hline Roe & 19.41 & 14.24 & 13.53 & -0.71 & -4.99 \\
\hline
\end{tabular}

Based on the company's financial data over the years, the following uses the traditional DuPont financial analysis system to analyze its financial position and operating results from three aspects: profitability, operating ability and solvency.

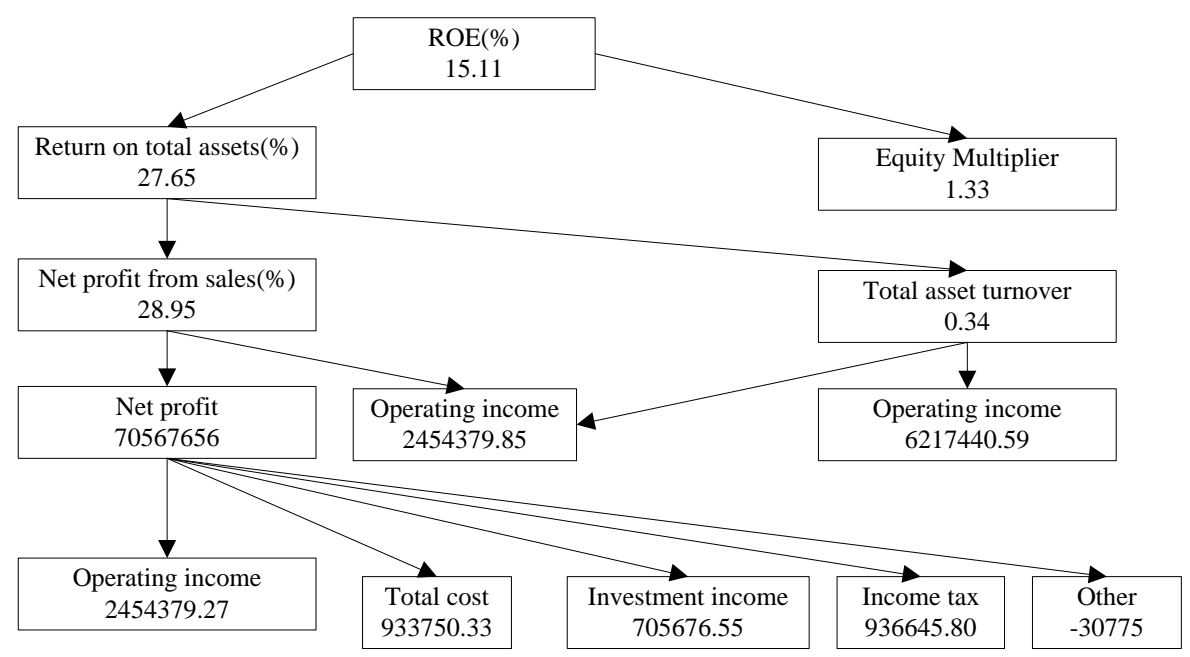

Fig. 3. A company DuPont financial analysis figure 
Through the case analysis of A Company, it is revealed that our cash flow has a special information function. It can gain insight into the company's earnings manipulation and report decoration, identify the company's financial risk, and evaluate its liquidity. The analysis of cash flow is to determine the company's true financial status A powerful tool should develop a cash flow analysis system as soon as possible "but it should be noted that this article emphasizes the information function of cash flows and the role of the introduction of cash flow indicators, but it is not a complete negation of the traditional DuPont financial analysis system" A series of traditional financial indicators and cash flow indicators based on the occurrence system are not exclusive. They are highly complementary in reflecting the financial status and operating results of the enterprise, and reflect the accounting information of the enterprise from two different dimensions. This point, many western scholars have proved through empirical research. "According to this, the author introduced cash flow indicators to the DuPont financial analysis system, and made a series of traditional indicators and cash flow indicators cleverly combined to try to build a more complete New comprehensive financial analysis system.

\section{SUMMARY}

Through the analysis of the return rate of financial rights and interests of company A, it is found that the total asset cash return rate has the most obvious influence on the return rate of owner's rights and interests, and the cash collection capacity of the enterprise's daily business activities is declining. Therefore, it is necessary to timely safeguard the owner's rights and interests of the enterprise and strive to improve the cash return value of the enterprise.

For the enterprise, on the one hand, it needs to reuse the existing market recognition to give full play to its brand value, continuously expand the marginal profit of products, firmly control the existing market share, continuously expand its share by using the higher market credibility, actively speed up capital turnover, control various expenses, strictly control costs, and at the same time, on the premise of safety, it can consider using part of the working capital for investment to improve the income of assets. In terms of sales, we should pay attention to diversified marketing strategies and adopt more marketing strategies to continuously improve the company's profit margin and profit level.

\section{REFERENCES}

[1] Zhang Xianye, Chen Youbang. Financial Analysis (Seventh Edition) [M]. Dongbei University of Finance and Economics Press.

[2] Shan Jiemin. Analysis of financial statements of listed companies[M]. Fudan University press, 2005. (3)
[3] Fifteen years of Wuliangye liquor grandly launched, opening the curtain of building a Chinese luxury brand[J]. Business culture, 2007

[4] Wang Junhong, Analysis of financial statements based on strategy: Tai Chi Group as an example[D]. Nanjing University of Science and Technology, 2012

[5] Liang hao, The Impact of Low-carbon Economy on China's Enterprise Finance: An Analysis Based on the Financial Environment Starting Point[J]. Accounting Research, 2010 (15) : 47-49

[6] Wen Sunbin, Huang Haolan, Enterprise Performance Evaluation of Stakeholder Value OrientationApplication Case of Performance Prism[J]. Accounting research. 2009 (4) : 63-68

[7] Zhang Jun, Xiao Fang, DuPont Analysis: Defects, Improvements and Prospects[J]. Journal of Inner Mongolia University of Finance and Economics, 2010 (1) : 88-90

[8] Luo Fang, Thoughts on Improving the Current Financial Analysis Index System[J]. Accounting Monthly, 2010 (4) :6-7.

[9] Douglas J. Cumming Venture Capital: Investment Strategies, Structures, and Poliocies [M]. John Wiley\&Sons, Inv., Hoboken, New Jersey, 2010

[10] David P. Baron. Managerial contracting and corporate social responsibility[J]. Journal of Public Economics, 2008(92):268-288. 